ScIDice

\section{Effect of RANKL Inhibitor Osteoprotegerin - FC on Orthodontic Tooth Movement - A Systematic Review of Animal Studies}

ISSN: $2377-8075$

Research Article

Arathi Murugesan ${ }^{1 *}$, Saravana Dinesh S.P 2

${ }^{1}$ Department of Orthodontics and Dentofacial Orthopedics, Saveetha Dental College and Hospitals, Saveetha Institute of Medical and Technical Sciences, Saveetha University, Chennai, India. Postcode- 600077, India.

${ }^{2}$ Professor and Head of the Department, Department of Orthodontics and Dentofacial Orthopedics, Saveetha Dental College and Hospitals, Saveetha Institute of Medical and Technical Sciences, Saveetha University, Chennai, India.

\title{
Abstract
}

Objective: The objective of this review was to systematically evaluate and appraise the quality of all the animal studies done to study the effect of OPG in inhibiting orthodontic tooth movement.

Methods: The protocol for the systematic review was registered in PROSPERO. Three electronic databases were searched for articles until February 2020. Hand searching of articles from the reference list of selected articles was also done. Animal studies which simulated orthodontic tooth movement after injecting osteoprotegerin and evaluated the rate of tooth movement were included for the review. Data collection, risk of bias and study quality was assessed by the two authors individually. SYRCLE's tool was used for risk of bias assessment whereas ARRIVE guidelines were used to check the study quality. The level of evidence and grade of recommendation was assessed using the OCEBM table.

Results: The search strategy identified a total 163 studies, of which 5 were included for the systematic review. Two studies had low risk of bias while the other three studies had unclear risk of bias. All the studies were of moderate quality according to the ARRIVE guidelines. The result of all the studies emphasized that osteoprotegerin was effective in inhibiting orthodontic tooth movement. Level of evidence ' $\mathrm{V}$ ' and Grade of recommendation 'D' was identified.

Conclusion: From the available evidence it can be said that osteoprotegerin is effective in inhibiting orthodontic tooth movement. Before it can be directly incorporated into human trials, it is safe to conduct these studies on nude mice. This is to negotiate the alterations in immune-inflammatory response in rats produced by human OPG-Fc.

Keywords: RANKL Inhibitor; Osteoprotegerin; Tooth Movement; Systematic Review.

\section{Introduction}

\section{Rationale}

In orthodontics, anchorage is prevention of unwanted tooth movement. Anchorage has an important role in the orthodontic treatment of almost all types of malocclusions. Good anchorage control helps to achieve excellent treatment results. It means that there is a minimal or no movement of the anchorage unit during the orthodontic treatment. The movement of the anchorage unit can be related to the Newton's Third Law of Motion, where every action has an equal and opposite reaction. Here, the movement of the desired teeth is the "action", whereas movement of the anchorage unit is the "reaction" [1]. Various methods have been designed to enhance the anchorage control, namely, headgears, transpalatal arch, Nance palatal arch, lingual stabilizing arch, intermaxillary elastics, miniscrews, mini-plates, mini-implants, pharmacological agents etc.

The conventional methods of anchorage control such as headgears and intermaxillary elastics required high patient compliance and also the increasing esthetic demands among the patients made the use of these aids questionable. Studies have also shown that transpalatal arch, Nance palatal arch, lingual stabilizing arch were effective only when used with other adjunctive aids for anchorage

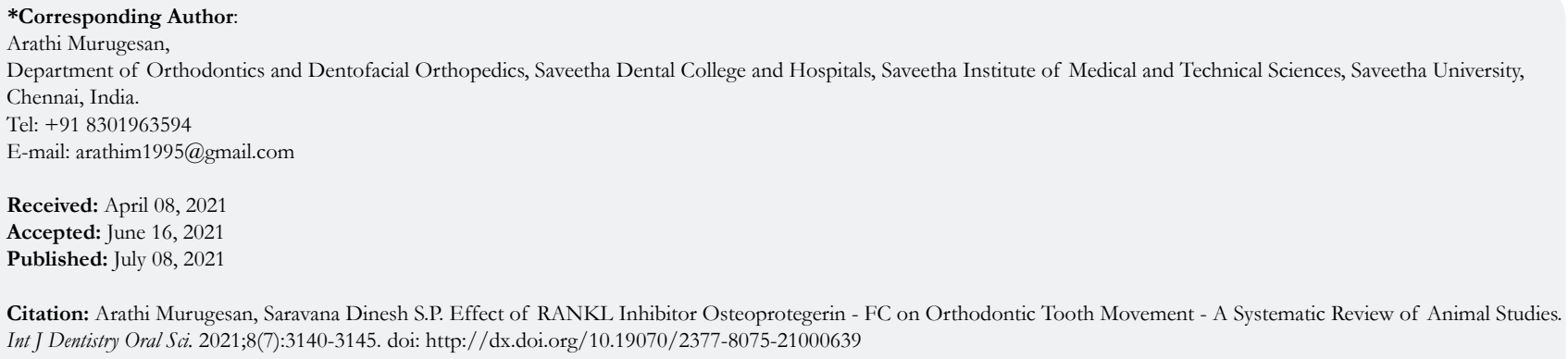

Copyright: Arathi Murugesan ${ }^{\circ}$ 2021. This is an open-access article distributed under the terms of the Creative Commons Attribution License, which permits unrestricted use, distribution and reproduction in any medium, provided the original author and source are credited. 
control [2, 3]. Moreover patients find it difficult to talk with these appliances in place and also the chances of iatrogenic injuries and allergy are also high. Temporary anchorage devices such as miniplates, mini-screws and mini-implants are known for providing absolute anchorage. Even though this is an advantage, there are some drawbacks with these intraoral skeletal anchorage devices, such as, damage to the surrounding structures such as tooth root, nerve or blood vessel damage, penetration into the nasal cavity or maxillary sinus, implant fracture during insertion or removal, soft tissue inflammation. The stability of the mini-implants or screws also depends on the quantity and quality of the bone [4, 5]. Given these disadvantages, we can search for pharmacological agents which can prevent the underlying biological events that take place during orthodontic tooth movement.

The basis for orthodontic tooth movement is the activity of osteoblasts and osteoclasts which are responsible for bone formation and bone resorption respectively. Osteoclast differentiation is regulated by receptor activator of nuclear factor $\mathrm{kB}$ (RANK)which is found on mature osteoclasts and their precursors. The RANK receptor is activated by RANK ligand (RANKL) seen on the surface of osteoblasts and periodontal ligament (PDL) cells. This is the critical step involved in the process of bone resorption $[6,7]$. Conversely, osteoprotegerin (OPG) acts as a competitive inhibitor of RANK by binding to RANKL and preventing osteoclastogenesis and bone resorption [8]. OPG reverses osteoporosis [9] and also increases bone strength by improving cortical and trabecular bone architecture [10]. Considering these properties of OPG, it shows that it can be used for anchorage control in orthodontics by preventing bone resorption in relation to the anchor unit.

\section{Objective}

The objective of this review was to systematically evaluate and appraise the quality of all the animal studies done regarding the effect of OPG in inhibiting orthodontic tooth movement.

\section{Materials And Methods}

\section{Protocol and registration}

The protocol for the systematic review was registered in PROSPERO (ID- CRD42019150387). PRISMA statement was followed for developing the protocol as well as during conduct and reporting [11].

\section{Eligibility criteria}

\section{Inclusion criteria}

- Studies involving healthy animals with orthodontic appliance exerting force on the molars

- Administration of osteoprotegerin injection during the start of force application

- Rate of anchorage loss compared between the osteoprotegerin group and control group which is injected with phosphate buffered saline solution or no injection

- Qualitative data on the rate of movement of molar

\section{Exclusion criteria}

- No control group or alternative drug used as control
- Review articles, systematic reviews and meta-analysis

\section{Information sources and search strategy}

Three electronic databases PubMed, Cochrane Library and Google Scholar were searched for articles until February 2020. The search strategy was designed by the two authors. There were no date restrictions used in the search strategy. Reference lists of the selected articles were also searched.

\section{Study selection}

The study articles were selected by two authors independently and then combined together. The preliminary selection of articles was based on the title and abstract. The selected articles were completely assessed according to all the inclusion and exclusion criteria. Disagreements among the authors were resolved by discussions. Authors of the respective articles were contacted in case of any unreported data.

\section{Data collection and data items}

Data extraction was done by the same two authors independently and then combined. Any disagreements were resolved by discussion. Data collection forms were used to record the following details:

- Name of the first author and year of publication

- Characteristics of the animals

- Mode of tooth movement

- Particulars of intervention

- Outcomes measured

- Results

\section{Risk of bias in individual studies}

The risk of bias was assessed using SYRCLE's risk of bias tool by the same authors as mentioned above [12]. Disagreements were resolved by discussion.

\section{Summary measures and synthesis of results}

Meta-analysis was to be done if it was possible to combine the results of the included studies.

\section{Risk of bias across studies and additional analyses}

'Small study effects' and other additional subgroup analyses were planned if sufficient information could be extracted from the included studies. The level of evidence and grade of recommendation was assessed using Oxford Centre for Evidence-Based Medicine (OCEBM) [13].

\section{Results}

\section{Study selection}

The PRISMA flow chart for study selection is shown in Figure 1. A total of 163 articles were obtained. 162 articles were identified through electronic database searching and 1 article was identified from the reference list of the selected articles. 2 duplicate articles were removed from the total list 163 articles. 161 articles were 
screened and out of these 155 articles were excluded based on the title and abstract. 6 full text articles were assessed completely for eligibility and 1 was excluded since it was a hypothesis article. Therefore, finally 5 articles were included for qualitative synthesis in this systematic review [14-18].

\section{Study Characteristics}

The characteristics of the included studies are listed in Table I. All the studies were experimented on male rats. The methodology of the study was almost similar for all the studies except for the study by Keles et al [18]. Orthodontic force was applied using closed NiTi coil spring for a period of 3 to 4 weeks producing mesial movement of the molars. The intervention was given as a local injection adjacent to the molars. Tooth movement was measured from scanned images of study models which were obtained from polyvinyl siloxane impressions of the teeth. In study by Keles et al., [18] there was no mention about the Animal Welfare Committee approval; the orthodontic force was applied through a $\mathrm{Y}$ shaped stainless steel spring that exerted a buccal/palatal force to the molars; the intervention was given as a subcutaneous injection and the tooth movement was measured through radiographs. In study by Fernandez et al., [16,17] no treatment was performed on the contra lateral side because of the possible systemic effects of the drug. Fernandez et al. [16] and Keles et al. [18] also compared the effect of OPG to zoledronate and pamidronate respectively. Other than the tooth movement measurements, histomorphometric analysis and micro-computed tomography were done by Dunn et al. [14], Sydorak et al. [15] and Fernandez et al. [15-17]. Sydorak et al. [15] also did serum analysis to evaluate the circulating levels of OPG. Osteoclast recruitment rate and apoptosis was assessed by Keles et al. [18]. Rate of incisor retraction and the subsequent anchorage loss ratio was evaluated in the studies by Dunn et al. [14] and Sydorak et al. [15]. The study quality was moderate for all the studies according to the Animal Research: Reporting in Vivo Experiments (ARRIVE) guidelines [19].

\section{Risk of bias within studies}

Summary of risk of bias within the studies is presented in Table II. Studies by Dunn et al. [14] and Fernandez et al. [17] had low risk of bias while the other three studies $[15,16,18]$ had unclear risk of bias. The studies presented an unclear risk of bias in terms of randomization, allocation concealment, randomised housing of the animals, blinding of caregivers/investigators and information on confounding factors. Regarding the outcome assessor blinding, two studies $[14,17]$ were rated low and three were rated high $[15,16,18]$. All the studies except for the study by Keles et al. [18] had low risk of bias in the domain of selective outcome reporting.

\section{Results of individual studies}

Osteoprotegerin injection was effective in inhibiting orthodontic tooth movement [14-18]. OPG inhibited tooth movement more effectively compared to zoledronate and pamidronate $[15,17]$. OPG also increased the bone density and bone volume fraction in the site of injection [16-18]. Sydorak et al., [15] showed that microsphere encapsulated OPG had more localised effect compared to non encapsulated OPG of the same dosage whereas non-encapsulated OPG of higher dosage was the most effective in inhibiting tooth movement but entered the systemic circulation. RANK, Runx, vimentin, MMP-9 and tissue inhibitor metalloproteinase 1 immunoreactivity were reduced significantly in OPG treated animals [16, 17$]$.

\section{Risk of bias across studies and additional analyses}

With the available data from the included studies, it was not possible to do analyses for small study effects or other additional analyses. Level of evidence ' $\mathrm{V}$ ' and Grade of recommendation 'D' was identified using OCEBM table [13].

\section{Discussion}

\section{Summary of evidence}

The effect of pharmacological agents in inhibiting orthodontic tooth movement was studied by various authors. Most of the studies focused on the effect of bisphosphonates in preventing tooth movement by inhibiting bone resorption [20-23]. Even though bisphosphonates proved to be effective in inhibiting orthodontic tooth movement, these are not indicated for orthodontic use currently due to its potential side effect of osteonecrosis of the jaw $[24,25]$. It resides in the bone for a long time and the effects are irreversible $[22,23]$. Therefore, researchers started analysing the biology of the tooth movement and the cellular mediators involved in it. Thus came the RANKL inhibitors, which could inhibit the activity of RANKL by binding to RANK and prevent osteoclastogenesis [8].

The RANKL inhibitor, osteoprotegerin, proves to be effective in inhibiting orthodontic tooth movement by preventing bone resorption [14-18]. Local injection of $5 \mathrm{mg} / \mathrm{kg}$ OPG, twice weekly

Figure 1. PRISMA flow chart.

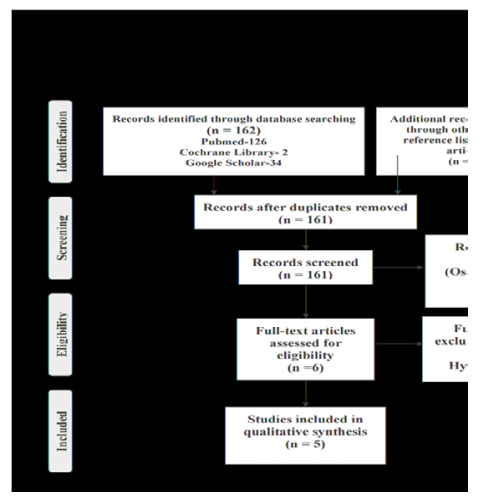


Table 1: Study characteristics.

\begin{tabular}{|c|c|c|c|c|c|}
\hline $\begin{array}{l}\text { Study( Name of } \\
\text { the first author } \\
\text { and year of } \\
\text { study) }\end{array}$ & $\begin{array}{l}\text { Subject character- } \\
\text { istics (Species, sex, } \\
\text { age, weight, total } \\
\text { number) }\end{array}$ & Tooth movement model & $\begin{array}{l}\text { Group characteristics ( number, } \\
\text { injecting agent, dosage, frequen- } \\
\text { cy, route, administration) }\end{array}$ & $\begin{array}{c}\text { Assessment of tooth move- } \\
\text { ment }\end{array}$ & Results \\
\hline $\begin{array}{c}\text { Dunn et al, } 2007 \\
{[14]}\end{array}$ & $\begin{array}{l}\text { Sprague-Dawley rats; } \\
\text { male; } 250-300 \mathrm{~g} ; 39\end{array}$ & $\begin{array}{l}\text { Closed coil Ni-Ti spring } \\
\text { from Mx M1 to Mx CI; } \\
\text { Force- } 54+/-2 \mathrm{~g} \\
21 \text { days }\end{array}$ & $\begin{array}{c}\text { Group 1: } 10 \text {; with appliance, OPG- } \\
\text { Fc 5mg/kg; twice weekly } \\
\text { Group 2: } 10 \text {; with appliance; OPG- } \\
\text { Fc } 0.5 \mathrm{mg} / \mathrm{kg} \text {; twice weekly } \\
\text { Group 3: 10; with appliance; PBS; } \\
\text { twice weekly } \\
3 \text { animals: no appliance; no injection } \\
3 \text { animals: no appliance; vehicle } \\
\text { injected } \\
3 \text { animals: no appliance; high dose } \\
\text { OPG } \\
\text { Site of injection- Palatal mucosa } \\
\text { adjacent to mesial surface of Mx M1 } \\
\text { Needle- } 33 \text { gauge microneedle } \\
\text { Sample size calculation- No }\end{array}$ & $\begin{array}{l}\text { Time interval- } 0,3,7,10,14,17 \text { and } \\
21 \text { days after appliance placement } \\
\text { PVS impression-stone mod- } \\
\text { els-scanned-magnified } 100 \mathrm{X} \\
\text { using Adobe Photoshop } \\
\text { Mesial movement of Mx M1- } \\
\text { distobuccal grove of Mx M1 } \\
\text { to the most distal surface of } \\
\text { Mx M3. } \\
\text { Distal movement of Mx CI - Me- } \\
\text { siodistal center of CI at the facial } \\
\text { gingival margin to distal surface } \\
\text { of Mx M3 }\end{array}$ & $\begin{array}{c}\text { After } 21 \text { days, } \\
\text { Mesial movement of Mx M1- } \\
\text { Group 1:0.20+/-0.03mm } \\
\text { Group 2:0.75+/-0.10mm } \\
\text { Group 3:0.93+/-0.07mm } \\
\text { Distal movement of Mx CI- } \\
\text { Group 1:1.05+/-0.03mm } \\
\text { Group 2:1.53+/-0.03mm } \\
\text { Group3: } 2.17+/-0.05 \mathrm{~mm} \\
\text { Ratio- Incisor retraction: molar move- } \\
\text { ment } \\
\text { Group1- } 5.2: 1 \\
\text { Group 2- } 2: 1 \\
\text { Group 3- 2.3:1 }\end{array}$ \\
\hline $\begin{array}{c}\text { Keles et al, } 2007 \\
{[18]}\end{array}$ & $\begin{array}{l}\text { C57Bl/ } 6 \text { mice; male; } \\
8 \text { week }\end{array}$ & $\begin{array}{l}0.2 \mathrm{~mm} \text { diameter coiled } \\
\text { stainless steel wire fash- } \\
\text { ioned into a Y-shaped } \\
\text { spring from Mx M1 to } \\
\text { Mx CI } \\
\text { Experiment group-con- } \\
\text { stricted } \\
\text { Control group- passive }\end{array}$ & $\begin{array}{l}\text { Group 1: Sterile saline with Pamidro- } \\
\text { nate } 5 \mathrm{mg} / \mathrm{kg} \text {; daily up to } 8 \text { days } \\
\text { Group 2: Sterile saline with OPG } \\
10 \mathrm{mg} / \mathrm{kg} \text {; daily up to } 8 \text { days } \\
\text { Route of administration- subcutane- } \\
\text { ous injection } \\
\text { Sample size calculation- No }\end{array}$ & $\begin{array}{l}\text { Time interval- } 0,1,4,8 \text { and } 12 \text { days } \\
\text { Low speed dental X-ray film } \\
\text { exposed using HP Faxitron; } \\
\text { exposure time } 30 \text { s at } 30 \mathrm{~W} \text { - devel- } \\
\text { oped films scanned as tif file-dig- } \\
\text { itized using COREL DRAW } 11 \\
\text { software- magnified X50- tooth } \\
\text { movement calculated as one- } \\
\text { half of the intermolar distance } \\
\text { between the bonded wire tips }\end{array}$ & $\begin{array}{c}\text { After } 8 \text { days, } \\
\text { Molar tooth movement- } \\
\text { 1.Control- } 0.06+/-0.02 \mathrm{~mm} \\
\text { Pamidronate- } 0.04+/-0.01 \mathrm{~mm} \\
\text { 2. Control- } 0.07+/-0.02 \mathrm{~mm} \\
\text { OPG- } 0.02+/-0.06 \mathrm{~mm}\end{array}$ \\
\hline $\begin{array}{l}\text { Fernandez et al, } \\
2016[17]\end{array}$ & $\begin{array}{l}\text { Sprague-Dawley rats; } \\
\text { male; } 6 \text { months; } 420- \\
\quad 450 \mathrm{~g} ; 42\end{array}$ & $\begin{array}{c}\text { Super elastic Ni-Ti closed } \\
\text { coil spring from right Mx } \\
\text { M1 to anterior mini-screw } \\
\text { (6mm length) placed } \\
\text { behind and between the } \\
\text { roots of the Mx incisors } \\
\text { Force- } 50 \mathrm{~g} \\
21 \text { days }\end{array}$ & $\begin{array}{c}\text { Group 1: 21; with appliance; } 50 \mu 1 \\
\text { PBS with human OPG-Fc } 5 \mathrm{mg} / \mathrm{kg} \text {; } \\
\text { twice weekly } \\
\text { Group 2: } 21 \text {, with appliance; } 50 \mu 1 \\
\text { PBS vehicle } \\
\text { Site of injection- palatal mucosa; } \\
\text { mesial and distal surface of right } \\
\text { Mx M1 and vestibule above the M1; } \\
\text { 3/10ml syringe } \\
\text { Sample size calculation- Yes }\end{array}$ & $\begin{array}{l}\text { Time interval- } 7,14 \text { and } 21 \text { days } \\
\text { PVS impressions-die stone- } \\
\text { scanned at } 1400 \text { dpi- magnified } \\
\text { 300X using Adobe Photoshop }\end{array}$ & $\begin{array}{l}\text { After } 21 \text { days, } \\
\text { Mesial movement of molar- } \\
\text { Group 1: } 0.22+/-0.01 \mathrm{~mm} \\
\text { Group 2: } 0.98+/-0.05 \mathrm{~mm}\end{array}$ \\
\hline $\begin{array}{l}\text { Fernandez et al, } \\
2016 \text { [16] }\end{array}$ & $\begin{array}{l}\text { Sprague Dawley rats; } \\
\text { male; } 420-460 \mathrm{~g} ; 36\end{array}$ & $\begin{array}{l}\text { Super elastic Ni-Ti closed } \\
\text { coil spring from right } \mathrm{Mx} \\
\text { M1 to anterior mini-screw } \\
\text { (6mm length) placed } \\
\text { behind and between the } \\
\text { roots of the Mx incisors } \\
\text { Force- } 50 \mathrm{~g} \\
21 \text { days }\end{array}$ & $\begin{array}{c}\text { Group 1: } 12 \text {; with appliance; } 50 \mu \mathrm{l} \\
\text { PBS with } 16 \mu \mathrm{g} \text { zoledronate; single } \\
\text { dose } \\
\text { Group 2: } 12 \text {; with appliance; } 50 \mu \mathrm{l} \\
\text { PBS with human OPG-Fc } 5 \mathrm{mg} / \mathrm{kg} \text {; } \\
\text { twice weekly } \\
\text { Group 3: } 12 \text {; with appliance; } 50 \mu \mathrm{l} \\
\text { PBS } \\
\text { Site of injection- palatal mucosa; } \\
\text { mesial and distal surface of right Mx } \\
\text { M1; 3/10ml syringe } \\
\text { Sample size calculation- Yes }\end{array}$ & $\begin{array}{l}\text { Time interval- } 7,14 \text { and } 21 \text { days } \\
\text { PVS impressions-die stone- } \\
\text { scanned- magnified } 100 \mathrm{X} \text { using } \\
\text { Adobe Photoshop }\end{array}$ & $\begin{array}{l}\text { After } 21 \text { days, } \\
\text { Mesial movement of molar- } \\
\text { Group 1: } 0.30+/-0.01 \mathrm{~mm} \\
\text { Group 2: } 0.21+/-0.01 \mathrm{~mm} \\
\text { Group 3: } 0.99+/-0.03 \mathrm{~mm}\end{array}$ \\
\hline $\begin{array}{c}\text { Sydorak et al, } 2019 \\
{[15]}\end{array}$ & $\begin{array}{l}\text { Sprague Dawley rats; } \\
\text { male; 360g; } 42\end{array}$ & $\begin{array}{l}\text { Ni-Ti coil spring from } \mathrm{Mx} \\
\text { M1 to Mx CI } \\
\text { Force- } 25 \mathrm{~g} \\
28 \text { days }\end{array}$ & $\begin{array}{c}\text { Group 1: 6; with appliance; empty } \\
\text { microspheres; single dose } \\
\text { Group 2: 6; with appliance; } 1 \mathrm{mg} / \\
\text { kg microsphere encapsulated OPG; } \\
\text { single dose } \\
\text { Group 3: 6; with appliance; } 1 \mathrm{mg} / \mathrm{kg} \\
\text { non-encapsulated OPG; single dose } \\
\text { Group 4: 6; with appliance; } 5 \mathrm{mg} / \\
\text { kg non-encapsulated OPG; multiple } \\
\text { dose-every } 3 \text { days once up to } 28 \text { days } \\
\text { Group 5: 6; no appliance; empty } \\
\text { microspheres; single dose } \\
\text { Group 6: 6; no appliance; } 1 \mathrm{mg} / \mathrm{kg} \\
\text { microsphere encapsulated OPG; } \\
\text { single dose } \\
\text { Group 7: 6; no appliance; } 1 \mathrm{mg} / \mathrm{kg} \\
\text { non-encapsulated OPG; single dose } \\
\text { Site of injection- palatal mucosa } \\
\text { adjacent to the mesial surface of } \\
\text { Mx M1 } \\
\text { Sample size calculation- No }\end{array}$ & $\begin{array}{l}\text { PVS impressions- stone models- } \\
\text { scanned at } 1200 \text { dpi- magnified } \\
\text { 300X using Adobe Photoshop } \\
\text { Mesial movement of Mx M1- } \\
\text { distal grove of Mx M1 to the } \\
\text { distal surface of Mx M3. } \\
\text { Distal movement of Mx CI - } \\
\text { Facial surface of Mx CI at the } \\
\text { gingival margin to distal surface } \\
\text { of Mx M3 }\end{array}$ & $\begin{array}{c}\text { After } 28 \text { days, } \\
\text { Mesial movement of Mx M1- } \\
\text { Group 1: } 0.8+/-0.1 \mathrm{~mm} \\
\text { Group 2: } 0.6+/-0.1 \mathrm{~mm} \\
\text { Group 3: } 0.8+/-0.1 \mathrm{~mm} \\
\text { Group 4: } 0.2+/-0.1 \mathrm{~mm} \\
\text { Distal movement of Mx CI- } \\
\text { Group 2: no reduction compared to } \\
\text { Group 1 } \\
\text { Group 3: no reduction compared to } \\
\text { Group } 1 \\
\text { Group 4: Significant reduction com- } \\
\text { pared to Group } 1,2 \text { and } 3 \\
\text { Ratio- Incisor retraction : mesial molar } \\
\text { movement } \\
\text { Group 2: } 1.4 \text { times greater compared } \\
\text { to Group } 1 \\
\text { Group 3: No significant difference } \\
\text { compared to Group } 1 \\
\text { Group 4: } 2.3 \text { times greater when com- } \\
\text { pared to Group } 1 \\
\text { 1.7 times greater when compared to } \\
\text { Group } 3\end{array}$ \\
\hline
\end{tabular}

Ni-Ti- Nickel Titanium; OPG-Fc-human recombinant Osteoprotegerin; PBS- phosphate buffered saline; Mx- maxilla; M1-first molar; M3-third molar; CI- central incisor; PVS- polyvinyl siloxane

was effective in significantly reducing the mesial movement of molar without inhibiting the distal movement of the anteriors [14-17]. Sydorak et al., in his study showed that $5 \mathrm{mg} / \mathrm{kg}$ of nonencapsulated OPG was more effective in molar inhibition than a local injection of microsphere encapsulated $1 \mathrm{mg} / \mathrm{kg}$ OPG. But the systemic circulation of OPG was high in animals injected with $5 \mathrm{mg} / \mathrm{kg}$ of non-encapsulated OPG [15]. Therefore, localising the action of OPG by microsphere encapsulation could be a safer option in order to prevent unwanted systemic effects. OPG is not only known to inhibit orthodontic tooth movement, but it is 
Table 2. Summary of risk of bias assessment.

\begin{tabular}{|c|c|c|c|c|c|c|c|c|c|c|c|}
\hline \multirow{2}{*}{ Study } & \multicolumn{10}{|c|}{ Signaling questions } & $\mathbf{9}$ \\
\cline { 2 - 12 } & $\mathbf{1}$ & $\mathbf{2}$ & $\mathbf{3}$ & $\mathbf{4}$ & $\mathbf{5}$ & $\mathbf{6}$ & $\mathbf{7}$ & $\mathbf{8}$ & $\mathbf{9}$ & $\mathbf{1 0}$ & Summary \\
\hline $\begin{array}{c}\text { Dunn et al, } \\
2007[14]\end{array}$ & Unclear & Low & Unclear & Unclear & Unclear & Unclear & Low & Low & Low & Unclear & Low \\
\hline $\begin{array}{c}\text { Keles et al, } \\
2007[18]\end{array}$ & Unclear & Unclear & Unclear & Unclear & Unclear & Unclear & High & Unclear & Unclear & Unclear & Unclear \\
\hline $\begin{array}{c}\text { Fernandez } \\
\text { et al, 2016 } \\
{[17]}\end{array}$ & Unclear & Low & Unclear & Unclear & Unclear & Unclear & Low & Low & Low & Unclear & Low \\
\hline $\begin{array}{c}\text { Fernandez } \\
\text { et al, 2016 } \\
{[16]}\end{array}$ & Unclear & Low & Unclear & Unclear & Unclear & Unclear & High & Low & Low & Unclear & Unclear \\
\hline $\begin{array}{c}\text { Sydorak } \\
\text { et al, 2019 } \\
{[15]}\end{array}$ & Unclear & Low & Unclear & Unclear & Unclear & Unclear & High & Low & Low & Unclear & Unclear \\
\hline
\end{tabular}

1-Was the allocation sequence adequately generated and applied? ; 2- Were the groups similar at baseline or were they adjusted for confounders in the analysis? ; 3- was the allocation to different to groups adequately concealed during the study? ; 4-Were the animals randomly housed during the assessment? ; 5- Were the caregivers and/or investigators blinded from knowledge which intervention each animal received during the experiment? 6- Were animals selected at random for outcome assessment? ; 7- Was the outcome assessor blinded? ; 8. Were incomplete outcome data adequately addressed? ; 9- Are reports of the study free of selective outcome reporting? ; 10. Was the study apparently free of other problems that could result in high risk of bias?

also a potential inhibitor post-orthodontic tooth relapse [26, 27$]$. Unlike bisphosphonates, RANKL inhibitors do not reside in the bone and their effects are reversible [28].

\section{Strengths and limitations}

This systematic review was based on the PRISMA guidelines. Electronic databases were searched using various combinations of search terms. All potentially eligible studies up to October 2019 were included in this review. Article screening, data extraction, assessment of study characteristics, risk of bias as well as assessment of level of evidence were performed independently by two authors and were combined together. All quality assessments were done based on the respective universal guidelines. Any disagreements aroused were resolved by discussion. All efforts were made to reduce the level of bias in the review.

The major limitation of the review would be the methodology of the included studies which used human recombinant OPG in animals. The dosage and the frequency of the OPG-Fc used in these animal studies might be higher than the effective human dosage as human OPG-Fc could alter the immune-inflammatory response in the rats [29]. Other limitations were that the database search was restricted to English language and hand search for the articles were not done. Also meta-analyses and other additional analysis could not be done with the available data.

\section{Recommendations for future research}

Before employing these results directly into human trials, it is better to study the dosage and frequency of OPG administration in nude mice that better resembles a human subject [30]. It is also important to carry out animal studies to find the long term local and systemic effects of OPG-Fc injection.

\section{Conclusion}

According to the results of this systematic review, osteoprote- gerin is effective in inhibiting orthodontic tooth movement and it can be used to enhance anchorage control during canine-retraction, en-mass anterior retraction, and various other orthodontic tooth movements, taking into consideration the possible systemic effects it can cause.

\section{References}

[1]. Li Y, Tang L. Local delivery of osteoprotegerin may be a way of reinforcing orthodontic anchorage. Med Hypotheses. 2009 Feb;72(2):178-9. PubmedPMID: 18951727.

[2]. Diar-Bakirly S, Feres MF, Saltaji H, Flores-Mir C, El-Bialy T. Effectiveness of the transpalatal arch in controlling orthodontic anchorage in maxillary premolar extraction cases: A systematic review and meta-analysis. Angle $\mathrm{Or}$ thod. 2017 Jan;87(1):147-158. PubmedPMID: 27504820.

[3]. Fichera G, Greco M, Leonardi R. Effectiveness of the passive lingual arch for $\mathrm{E}$ space maintenance in subjects with anterior or posterior rotation of the mandible: a retrospective study. Med PrincPract. 2011;20(2):165-70. PubmedPMID: 21252574

[4]. Park J, Cho HJ. Three-dimensional evaluation of interradicular spaces and cortical bone thickness for the placement and initial stability of microimplants in adults. Am J OrthodDentofacialOrthop. 2009 Sep;136(3):314. e1-12; discussion 314-5. PubmedPMID: 19732658.

[5]. Kuroda S, Tanaka E. Risks and complications of miniscrew anchorage in clinical orthodontics. Japanese Dental Science Review. 2014 Nov 1;50(4):79-85.

[6]. Kobayashi Y, Udagawa N, Takahashi N. Action of RANKL and OPG for osteoclastogenesis. Crit Rev Eukaryot Gene Expr. 2009;19(1):61-72. PubmedPMID: 19191757.

[7]. Grimaud E, Soubigou L, Couillaud S, Coipeau P, Moreau A, Passuti N, et al. Receptor activator of nuclear factor kappaB ligand (RANKL)/osteoprotegerin (OPG) ratio is increased in severe osteolysis. Am J Pathol. 2003 Nov;163(5):2021-31. PubmedPMID: 14578201.

[8]. Simonet WS, Lacey DL, Dunstan CR, Kelley M, Chang MS, Lüthy R, et al. Osteoprotegerin: a novel secreted protein involved in the regulation of bone density. Cell. 1997 Apr 18;89(2):309-19. PubmedPMID: 9108485.

[9]. Min H, Morony S, Sarosi I, Dunstan CR, Capparelli C, Scully S, et al. Osteoprotegerin reverses osteoporosis by inhibiting endosteal osteoclasts and prevents vascular calcification by blocking a process resembling osteoclastogenesis. J Exp Med. 2000 Aug 21;192(4):463-74. PubmedPMID: 10952716.

[10]. Ominsky MS, Li X, Asuncion FJ, Barrero M, Warmington KS, Dwyer D, et al. RANKL inhibition with osteoprotegerin increases bone strength by improving cortical and trabecular bone architecture in ovariectomized rats. J Bone Miner Res. 2008 May;23(5):672-82. PubmedPMID: 18433301.

[11]. Liberati A, Altman DG, Tetzlaff J, Mulrow C, Gøtzsche PC, Ioannidis JP, et al. The PRISMA statement for reporting systematic reviews and meta- 
analyses of studies that evaluate healthcare interventions: explanation and elaboration. BMJ. 2009 Jul 21;339:b2700. PubmedPMID: 19622552.

[12]. Hooijmans CR, Rovers MM, de Vries RB, Leenaars M, Ritskes-Hoitinga M, Langendam MW. SYRCLE's risk of bias tool for animal studies. BMC Med Res Methodol. 2014 Mar 26;14:43. PubmedPMID: 24667063.

[13]. Oxford Centre for Evidence-based Medicine - Levels of Evidence (March 2009) - CEBM. CEBM 2009.

[14]. Dunn MD, Park CH, Kostenuik PJ, Kapila S, Giannobile WV. Local delivery of osteoprotegerin inhibits mechanically mediated bone modeling in orthodontic tooth movement. Bone. 2007 Sep;41(3):446-55. PubmedPMID: 17588510.

[15]. Sydorak I, Dang M, Baxter SJ, Halcomb M, Ma P, Kapila S, et al. Microsphere controlled drug delivery for local control of tooth movement. Eur J Orthod. 2019 Jan 23;41(1):1-8. PubmedPMID: 29608684.

[16]. Fernández-González FJ, López-Caballo JL, Cañigral A, Menéndez-Díaz I, Brizuela A, de Cos FJ, et al. Osteoprotegerin and zoledronate bone effects during orthodontic tooth movement. OrthodCraniofac Res. 2016 Feb;19(1):54-64. PubmedPMID: 26515913.

[17]. Fernández-González FJ, Cañigral A, López-Caballo JL, Brizuela A, Cobo T, de Carlos F, et al. Recombinant osteoprotegerin effects during orthodontic movement in a rat model. Eur J Orthod. 2016 Aug;38(4):379-85. PubmedPMID: 26293288.

[18]. Keles A, Grunes B, Difuria C, Gagari E, Srinivasan V, Darendeliler MA, et al. Inhibition of tooth movement by osteoprotegerin vs. pamidronate under conditions of constant orthodontic force. Eur J Oral Sci. 2007 Apr;115(2):131-6. PubmedPMID: 17451503.

[19]. Kilkenny C, Browne W, Cuthill IC, Emerson M, Altman DG; NC3Rs Reporting Guidelines Working Group. Animal research: reporting in vivo experiments: the ARRIVE guidelines. Br J Pharmacol. 2010 Aug;160(7):15779. PubmedPMID: 20649561

[20]. Ortega AJ, Campbell PM, Hinton R, Naidu A, Buschang PH. Local application of zoledronate for maximum anchorage during space closure. Am J OrthodDentofacialOrthop. 2012 Dec;142(6):780-91. PubmedPMID: 23195364.

[21]. Igarashi K, Mitani H, Adachi H, Shinoda H. Anchorage and retentive effects of a bisphosphonate (AHBuBP) on tooth movements in rats. Am J Orthod-
DentofacialOrthop. 1994 Sep;106(3):279-89. PubmedPMID: 8074093.

[22]. Liu C, Sun X, Chen Y, Hu M, Liang T. The effects of local administration of Zoledronate solution on the tooth movement and periodontal ligament. Zhonghua Kou Qiang Yi XueZaZhi. 2002 Jul;37(4):290-3. PubmedPMID: 12411180.

[23]. Kaipatur NR, Wu Y, Adeeb S, Stevenson TR, Major PW, Doschak MR. Impact of bisphosphonate drug burden in alveolar bone during orthodontic tooth movement in a rat model: a pilot study. Am J OrthodDentofacialOrthop. 2013 Oct;144(4):557-67. PubmedPMID: 24075664.

[24]. Markiewicz MR, Margarone JE 3rd, Campbell JH, Aguirre A. Bisphosphonate-associated osteonecrosis of the jaws: a review of current knowledge. J Am Dent Assoc. 2005 Dec;136(12):1669-74. PubmedPMID: 16383048.

[25]. Migliorati CA, Casiglia J, Epstein J, Jacobsen PL, Siegel MA, Woo SB. Managing the care of patients with bisphosphonate-associated osteonecrosis: an American Academy of Oral Medicine position paper. J Am Dent Assoc. 2005 Dec;136(12):1658-68. PubmedPMID: 16383047.

[26]. Hudson JB, Hatch N, Hayami T, Shin JM, Stolina M, Kostenuik PJ, et al. Local delivery of recombinant osteoprotegerin enhances postorthodontic tooth stability. Calcif Tissue Int. 2012 Apr;90(4):330-42. PubmedPMID: 22382900.

[27]. Schneider DA, Smith SM, Campbell C, Hayami T, Kapila S, Hatch NE. Locally limited inhibition of bone resorption and orthodontic relapse by recombinant osteoprotegerin protein. OrthodCraniofac Res. 2015 Apr;18Suppl 1:187-95. PubmedPMID: 25865548.

[28]. Capparelli C, Morony S, Warmington K, Adamu S, Lacey D, Dunstan CR, et al. Sustained antiresorptive effects after a single treatment with human recombinant osteoprotegerin $(\mathrm{OPG})$ : a pharmacodynamic and pharmacokinetic analysis in rats. J Bone Miner Res. 2003 May;18(5):852-8. PubmedPMID: 12733724.

[29]. Hienz SA, Paliwal S, Ivanovski S. Mechanisms of Bone Resorption in Periodontitis. J Immunol Res. 2015;2015:615486. PubmedPMID: 26065002.

[30]. Morony S, Capparelli C, Sarosi I, Lacey DL, Dunstan CR, Kostenuik PJ. Osteoprotegerin inhibits osteolysis and decreases skeletal tumor burden in syngeneic and nude mouse models of experimental bone metastasis. Cancer Res. 2001 Jun 1;61(11):4432-6. PubmedPMID: 11389072. 